\title{
Plasma Melatonin and Progesterone Profiles of Suffolk and Romney Marsh Ewes Implanted with Melatonin during Anoestrus Season at Lower Latitudes in Southern Hemisphere
}

\author{
Aya Sasa', Paula Almeida Rodrigues' ${ }^{2}$ Keico Okino Nonaka ${ }^{3}$, \\ Julio César de Carvalho Balieiro ${ }^{4} \&$ Lia Alencar Coelho ${ }^{5}$
}

\begin{abstract}
Background: The subcutaneous implants of melatonin are stimulatory and mimic the positive effects of short photoperiod on reproduction in small ruminants. This study investigated the daily plasma melatonin profiles in ewes treated with melatonin implants and kept under natural photoperiod in Southeastern Brazil. The plasma progesterone concentrations were also investigated before and after melatonin implantation.

Materials, Methods \& Results: Romney Marsh $(\mathrm{n}=11)$ and Suffolk $(\mathrm{n}=10)$ ewes, which had been isolated from rams for at least 2 months prior to the beginning of the trial, were randomly allocated in two groups based on melatonin implant treatment (with or without melatonin implant). For plasma melatonin concentration, 43 days after melatonin implantation and 3 days before the ram introduction blood samples were collected every 2 hours during 24 hours. For plasma progesterone concentrations, blood samples were collected every once to twice a week for 2 different periods: prior to melatonin implantation and 46 days after the melatonin implantation and at the same day of the introduction of rams. The hormonal concentrations were determined by the radioimmunoassay method (RIA). The data were analyzed according to MIXED procedure (SAS) as repeated measurements for random animal effects. The effect of melatonin treatment on plasma melatonin 24-h period varied according to the breed. At the dark-phase, there were no plasma melatonin differences $(P>0.05)$ between implanted and no-implanted $(228.02 \pm 58.39$ vs. $169.59 \pm 48.39)$ Romney Marsh ewes whereas for Suffolk ewes the plasma melatonin levels were higher in implanted (305.61 \pm $68.39 \mathrm{pg} / \mathrm{mL})$ than no-implanted $(151.26 \pm 38.35 \mathrm{pg} / \mathrm{mL})$ ones. At the light-phase, melatonin treatment effects could be evidenced and these differences $(P<0.01)$ consisted of higher melatonin values for implanted ewes and basal values for no-implanted ones in both breed groups. Before the melatonin implantation, the plasma progesterone levels were $<1 \mathrm{ng} / \mathrm{mL}$ for Romney Marsh $(0.41$ $\pm 0.02 \mathrm{ng} / \mathrm{mL})$ and Suffolk $(0.47 \pm 0.02 \mathrm{ng} / \mathrm{mL})$ ewes. During the ram introduction period, no melatonin treatment effect was observed on plasma progesterone concentrations in both breed groups, but 2 days after ram introduction the plasma progesterone concentrations increased the mean values $>$ than $1 \mathrm{ng} / \mathrm{mL}$ in implanted and no-implanted Suffolk ewes. In implanted Romney Marsh ewes the elevation of progesterone mean values was weak whereas in no-implanted Romney Marsh ewes the progesterone levels were maintained $<1 \mathrm{ng} / \mathrm{mL}$ during all the blood sample collection times.

Discussion: The melatonin treatment also produced a similar model of daily melatonin levels as reported previously by others, which is characterized by high plasma melatonin concentrations during the light phase of the day. The effect of melatonin implants on plasma melatonin profiles interacted with breed confirming an individual response to melatonin implantation which is proportional to genetic individual variation pattern of melatonin secretion. Before the melatonin implantation all Romney Marsh and Suffolk ewes were judged to be in non-ovulatory period (anoestrus) with plasma progesterone mean values lower than $1 \mathrm{ng} / \mathrm{mL}$. The melatonin treatment helped to induce the ovulatory activity in most of the ewes that were in anestrous at the time of melatonin implantation and the efficacy of this treatment depends on the individual variation in ovulatory response to ram introduction. In Southeastern Brazil., melatonin implant altered the daily plasma melatonin profiles of Suffolk and Romney Marsh ewes by increasing the melatonin levels during the light-phase of the day. Melatonin implant also induced an ovulatory response in Suffolk and Romney Marsh after the introduction of the rams. For no-implanted Suffolk ewes, the male effect is sufficient to provoke an ovulatory response.
\end{abstract}

Keywords: implant melatonin, male effect natural photoperiod, progesterone, sheep.

${ }^{1}$ Universidade Estadual de Mato Grosso do Sul (USMS), Aquidauana, MS, Brazil, ${ }^{2}$ Universidade de Franca (UNIFRAN), Franca, SP, Brazil. ${ }^{3}$ Universidade Federal de São Carlos (UFSCar), São Carlos, SP. ${ }^{4}$ Faculdade de Medicina Veterinária e Zootecnia (FMVZ), Universidade de São Paulo (USP), Pirassununga, SP. ${ }^{5}$ Faculdade de Zootecnia e Engenharia de Alimentos (FZEA), Universidade de São Paulo (USP), Pirassununga, SP. CORRESPONDENCE: L.A. Coelho [liac@ usp.br - Tel.: +55 (19) 35654066]. Departamento de Medicina Veterinária (ZMV), FZEA - USP. Av. Duque de Caxias Norte n. 225. CEP 13.635-900 Pirassununga, SP, Brazil. 


\section{INTRODUCTION}

In sheep, melatonin is an important photoperiodic modulation of reproductive seasonality [20] and the annual cyclic reproductive activity is initiated by the photoperiodic signal induced by decreasing daylength $[15,35]$. Melatonin secretion is limited to the dark phase of the light:dark cycle and the duration of its daily secretion is proportional to the length of night $[2,20]$. The modification of the secretory pattern of melatonin in response to changes in day length transmits photoperiodic information to the hypothalamuspituitary-gonad axis [36].

Effective mimicking of the temporal information transmitted to the reproductive axis by the progressive increase in the duration of the daily endogenous melatonin rhythm can be achieved by administration of exogenous melatonin [11,39]. It is well documented that subcutaneous implants of melatonin is stimulatory and mimic the positive effects of short photoperiod on reproduction in small ruminants $[1,4,17,37]$.

Although there are some studies describing the characteristic of daily blood melatonin profiles $[9,10,28]$ and also plasma progesterone concentrations [1] in ewes treated with melatonin implants, most of them were performed in high latitudes.

This study investigated the daily plasma melatonin profiles in ewes treated with melatonin implants and kept under natural photoperiod in Southeastern Brazil. The plasma progesterone concentrations were also investigated before and after melatonin implantation.

\section{MATERIALS AND METHODS}

Study conditions, locality, animals and management

The study was carried out during the period of September to December (spring and summer) at the Experimental Farm of the Faculty of Animal Science and Food Engineering (FZEA) - University of São Paulo (USP), Pirassununga, SP, Brazil. The city is located at $21^{\circ} 59$ southern latitude and $47^{\circ} 26$ western longitude from Greenwich at an altitude of $634 \mathrm{~m}$. The climate is subtropical with average annual rain precipitation and temperature of $1,300 \mathrm{~mm}$ and $21^{\circ} \mathrm{C}$, respectively [18]. The variation between the longest day $(13.5 \mathrm{~h})$ and the shortest day $(10.5 \mathrm{~h})$ of the year is only $2.6 \mathrm{~h}$ [7].

Twenty-one ewe Romney Marsh $(\mathrm{n}=11)$ and Suffolk $(n=10)$ ewes, which had been isolated from rams for at least 2 months prior to the beginning of the trial, were used. The ewes were $1.2 \pm 0.9$ years old and the mean live weights of Romney Marsh and Suffolk females were $43.3 \pm 0.2$ and $47.5 \pm 0.8 \mathrm{~kg}$, respectively. To induce male effect, 3 vasectomized adult rams of hair Santa Inês breed with no annual variation in breeding behavior [29], were used during the study. All the animals, previously vaccinated and dewormed, were confined in stalls and received feeding based on commercial ration, grass hay (Cynodon dactylon) cost-cross cultivar, twice a day, according to the nutritional requirements for sheep [24], and water ad libitum.

The ewes from each breed were randomly allocated in two groups based on melatonin implant treatment (with or without melatonin implant). On 19 October, half of the females of each group (6 Romney March and 5 Suffolk ewes) received a single subcutaneous implant at the base of the left ear containing $18 \mathrm{mg}$ melatonin $\left(\text { Melovine }{ }^{\circledR}\right)^{1}$. On 4 December (day 0), 46 days after melatonin implantation (day of implant removal), 3 aproned rams were introduced into the 2 groups to induce a ram effect [1].

\section{Blood sampling and hormone assay}

Blood samples were collected from the jugular vein contralateral to the site of implantation using vacuum tubes containing heparin as anticoagulant. Plasma was obtained by centrifugation and was stored at $-20^{\circ} \mathrm{C}$, before assays to determine plasma concentrations of melatonin and progesterone.

On 01 December, 43 days after melatonin implantation and three days before the ram introduction samples for plasma concentrations of melatonin were collected every $2 \mathrm{~h}$ during $24 \mathrm{~h}$. Blood collection during the dark phase was performed using a dim red light $(<1$ lux). Melatonin was assayed in duplicate $500-\mu \mathrm{L}$ aliquots of plasma using the direct radioimmunoassay method of Frazier et al. [14], modified by English et $a l$. [10]. Coefficients of variation were estimated by assaying 2 plasma pools (low and high concentrations of melatonin) of samples in the beginning and in the end of each assay (2 assays). The mean intra- and interassay for two plasma pools were $2.9 \%$ and $8.9 \%$, respectively. The detection limit of the assay was 5 $\mathrm{pg} / \mathrm{mL}$.

For plasma progesterone concentrations, samples were collected at the same time in the 
morning every once to twice a week for two different periods. The first period (Period 1) collection aimed to monitor the ovulatory status of ewes prior to melatonin implantation and lasted 18 days (beginning on 10 September and ended on 27 September). The second period (Period 2) collection was at the same day of the introduction of rams (Day 0) and 46 days after the melatonin implantation and lasted also 14 days (beginning on 4 December and ended on 21 December). Progesterone concentrations above $1 \mathrm{ng} / \mathrm{mL}$ were assumed to indicate the presence of corpora lutea and, therefore, ovulation but, if the concentrations were inferior to $1 \mathrm{ng} / \mathrm{mL}$ for a period superior to 10 days, the ewes were considered in anoestrus [23]. Plasma concentrations of progesterone were determined by the radioimmunoassay method (RIA), and samples were analyzed in duplicate using commercial kits (COAT-A-COUNT)2. The sensibility of the assay was $0.02 \mathrm{ng} / \mathrm{mL}$ and the inter- and intra-assay variation coefficients were 2.5 and $1.7 \%$, respectively. This RIA assay was previously validated for sheep [22].

\section{Statistical analysis}

Values regarding plasma melatonin $(\mathrm{pg} / \mathrm{mL})$ were treated according to MIXED procedure [34] as repeated measurements for random animal effects, using Linear Mixed Models. The causes of variation were melatonin treatment (Implanted and No-implanted), breed (Romney Marsh and Suffolk), the time (hour) of sample collection or the $24 \mathrm{~h}$-period (dark period and light- time) and the interaction between them. The same model was used for plasma progesterone with the following causes of variation: the melatonin treatment, breed, the day of sample collection and their interactions.

\section{RESULTS}

The statistical model revealed that the melatonin treatment affected significantly the daily plasma concentrations of melatonin of Suffolk and Romney Marsh ewes. The effect of melatonin treatment on plasma melatonin 24-h period varied according to the breed (Figure 1). There was no melatonin implantation effect on 24-h plasma melatonin concentrations in Romney Marsh ewes whereas the plasma melatonin levels were affected by melatonin implantation in Suffolk ewes with higher melatonin profiles during the light-phase of the day. In no-implanted Romney
Marsh and Suffolk ewes the amount of nocturnal melatonin detected was related to the extent of the dark-phase of day.
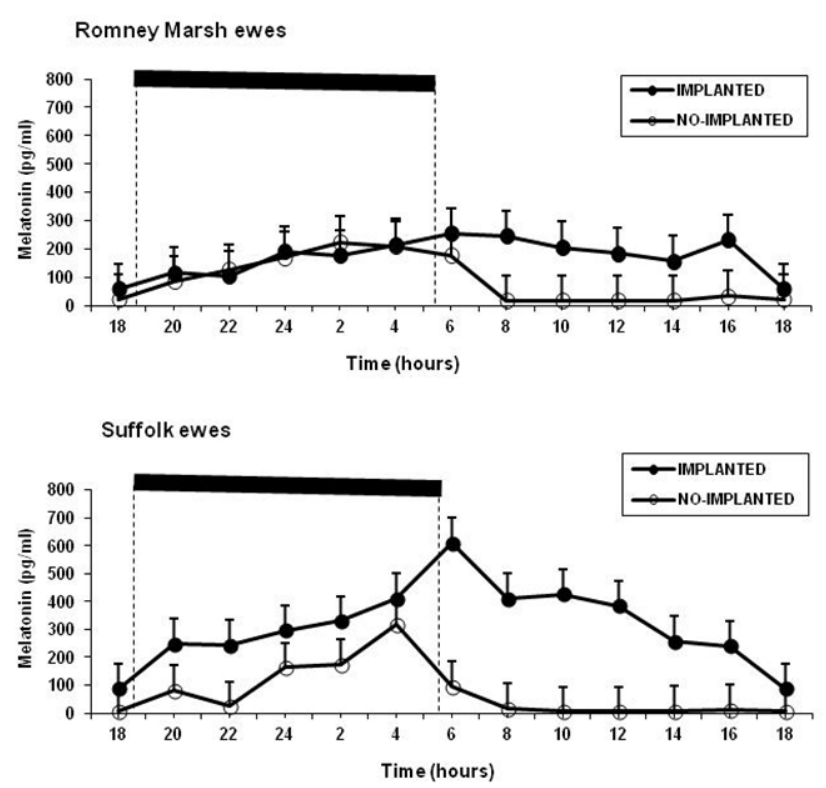

Figure 1. Plasma melatonin concentrations (mean \pm S.E.M.) in implanted and no-implanted Romney Marsh and Suffolk ewes determined at 2-hs intervals during a 24 -hs period at 43 days after melatonin implantation. The dark-phase of the day is indicated in upper panel. $* P<0.01$.

When the amount of melatonin detected during the light- and dark-phases was evaluated separately for Suffolk (Table 1) and Romney Marsh (Table 2) ewes, the interaction between melatonin treatment and the period of the day was also significant. At the dark-phase, there were no plasma melatonin differences $(P>0.05)$ between implanted and no-implanted $(228.02 \pm 58.39$ vs. $169.59 \pm$ 48.39) Romney Marsh ewes whereas for Suffolk ewes (Table 1) the plasma melatonin levels were higher in implanted $(305.61 \pm 68.39 \mathrm{pg} / \mathrm{mL})$ than no-implanted $(151.26 \pm 38.35 \mathrm{pg} / \mathrm{mL})$ ones. At the light-phase, melatonin treatment effects could be evidenced and these differences $(P<0.01)$ consisted of higher melatonin values for implanted ewes and basal values for no-implanted ones in both breed groups (Tables 1 and 2). Considering the breed factor, in implanted and no-implanted animals the plasma melatonin mean values during the darkphase were significantly higher than those values observed during the light-phase for Romney Marsh ewes (Table 2) but not for Suffolk ones (Table 1). 
Table 1. Plasma melatonin concentrations (mean \pm SEM) during the light-phase and the dark-phase of 24-h-period in melatonin implanted or no-implanted Suffolk ewes kept under natural photoperiodic conditions at lower latitudes.

\begin{tabular}{ccc}
\hline \multirow{2}{*}{$\begin{array}{c}\text { Experimental } \\
\text { groups }\end{array}$} & \multicolumn{2}{c}{ 24-h Periods } \\
\cline { 2 - 3 } & Light-phase & Dark-phase \\
\hline Implanted & $344.87 \pm 32.44^{\mathrm{Aa}}$ & $305.61 \pm 38.39^{\mathrm{Aa}}$ \\
No-Implanted & $20.48 \pm 32.44^{\mathrm{Bb}}$ & $151.26 \pm 38.39^{\mathrm{Ba}}$ \\
\hline
\end{tabular}

Values with different superscripts within the same column (A,B) or within the same row $(\mathrm{a}, \mathrm{b})$ are significantly different $(P<0.05)$ by Chi-square test.

Table 2. Plasma melatonin concentrations (mean \pm SEM) during the light-phase and the dark-phase of 24-h-period in melatonin implanted or no-implanted Romney Marsh ewes kept under natural photoperiodic conditions at lower latitudes.

\begin{tabular}{ccc}
\hline \multirow{2}{*}{$\begin{array}{c}\text { Experimental } \\
\text { groups }\end{array}$} & \multicolumn{2}{c}{ 24-h Period } \\
\cline { 2 - 3 } & Light-phase & Dark-phase \\
\hline Implanted & $145.77 \pm 45.90^{\mathrm{Ab}}$ & $228.02 \pm 58.39^{\mathrm{Aa}}$ \\
No-Implanted & $42.64 \pm 32.44^{\mathrm{Bb}}$ & $169.59 \pm 48.39^{\mathrm{Aa}}$ \\
\hline
\end{tabular}

Values with different superscripts within the same column (A, B) or within the same row $(\mathrm{a}, \mathrm{b})$ are significantly different $(P<0.05)$ by Chi-square test.

The plasma progesterone data collected before the melatonin implantation (11 to 27 September) revealed that no breed differences $(P>0.05)$ were observed during this period and the mean values were $0.41 \pm 0.02 \mathrm{ng} / \mathrm{mL}$ and $0.47 \pm 0.02 \mathrm{ng} / \mathrm{mL}$ for Romney Marsh and Suffolk ewes, respectively. The Figures 2 and 3 represent the plasma progesterone concentrations 46 days after melatonin implantation and at the same day (Day 0) of ram introduction. During the ram introduction period, no melatonin treatment effect was observed on plasma progesterone concentrations in both breed groups (Figure 2). At the same day and 2 days after ram introduction, the means of plasma progesterone were lower than $1 \mathrm{ng} / \mathrm{mL}$ in implanted and no-implanted Romney Marsh (Figure 2A) and Suffolk (Figure 2B) ewes, but after this the plasma progesterone concentrations increased the mean values above than $1 \mathrm{ng} /$ $\mathrm{mL}$ in implanted and no-implanted Suffolk ewes (Figure 2B). In implanted Romney Marsh ewes the elevation of progesterone mean values was weak whereas in no-implanted Romney Marsh ewes the progesterone levels were maintained $<1 \mathrm{ng} / \mathrm{mL}$ during all the blood sample collection times (Figure 2A). Considering progesterone breed differences, among implanted ewes (Figure 3A), no breed differences on plasma progesterone profiles were observed along the period of blood samples collection, exception in day 9 of ram introduction which plasma progesterone concentrations were higher $(P<0.05)$ in Suffolk than Romney Marsh ewes. Among no-implanted ewes (Figure 3B) after nine days of ram introduction, the Suffolk ewes showed a higher pattern of plasma progesterone concentration with mean values $>1 \mathrm{ng} / \mathrm{mL}$.
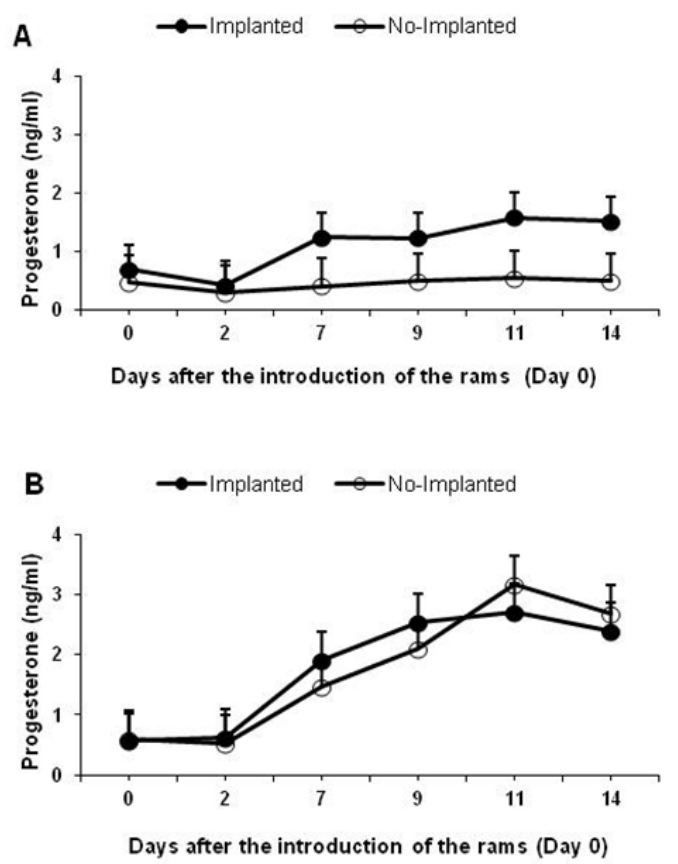

Figure 2. Plasma progesterone concentrations (mean \pm S.E.M.) in implanted and no-implanted Romney Marsh (A) and Suffolk (B) ewes determined at the same day of the introduction of the rams (Day 0) and 46 days after melatonin implantation. $P>0.05$.
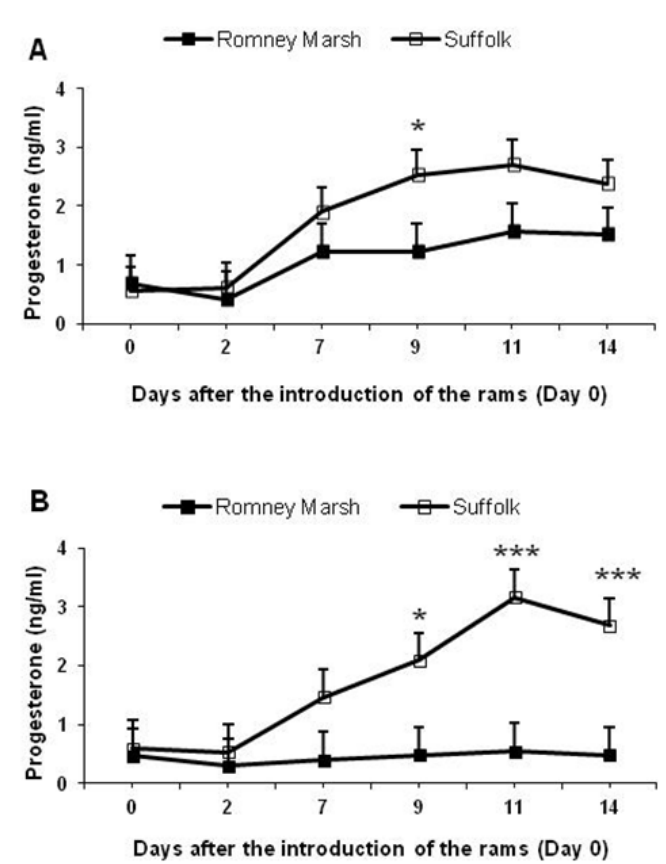

Figure 3. Plasma progesterone concentrations (mean \pm S.E.M.) in implanted (B) and no-implanted (B) Romney Marsh and Suffolk ewes determined at the same day of the introduction of the rams (Day 0) and 46 days after melatonin implantation. $* P<0.05 ; * * * P<0.001$. 
Regarding to plasma progesterone concentrations of individual implanted and no-implanted Suffolk (Figure 4) and Romney Marsh (Figure 5) ewes, four of five implanted and all of no-implanted Suffolk ewes showed a significant increased of progesterone levels
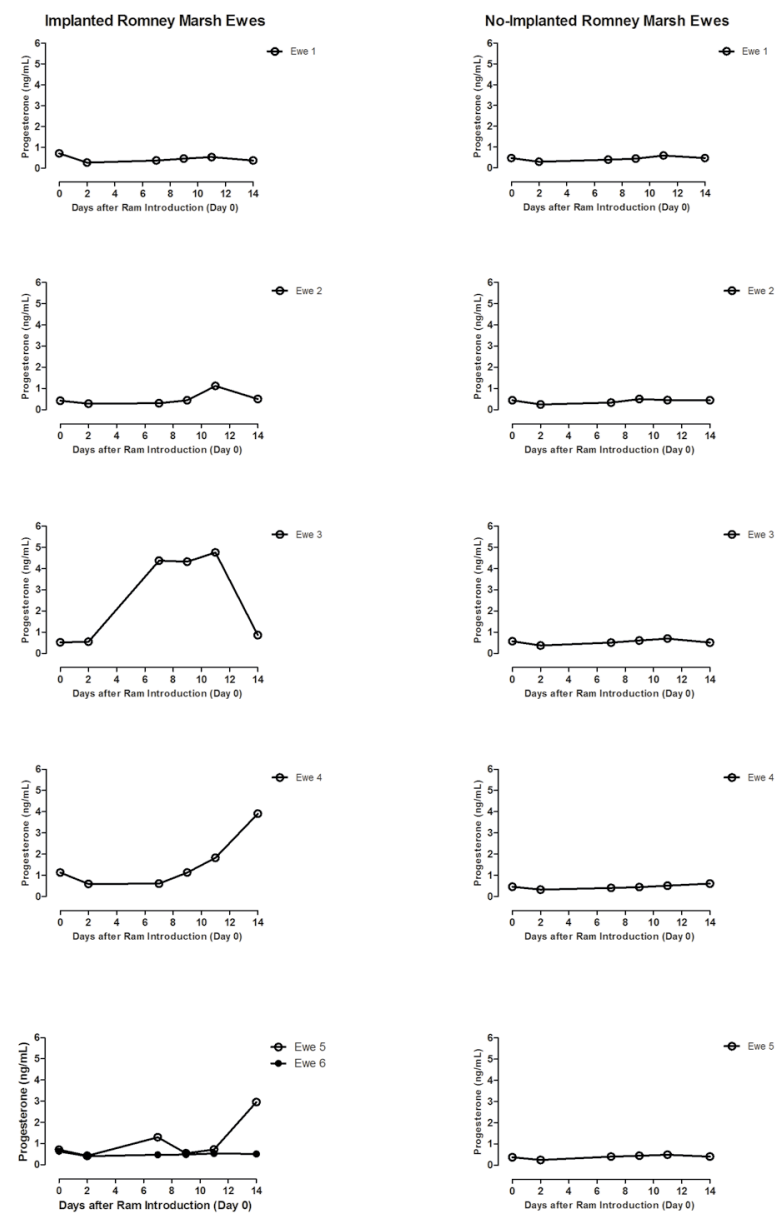

Figure 4. Individual plasma progesterone concentrations in melatonin implanted and no-implanted Suffolk ewes determined at the same day of the introduction of the rams (Day 0) and 46 days after melatonin implantation.

\section{DISCUSSION}

The present study describes the daily changes in plasma concentrations of melatonin in ewes living under natural light conditions at 21059'S which received melatonin implants during the spring season. This study also describes the plasma progesterone concentration before and after melatonin implantation.

The daily plasma melatonin pattern in Romney Marsh and Suffolk no-implanted ewes seems to be the same of those raised under natural or artificial conditions in lower, intermediate or higher latitudes in southern or northern hemispheres $[2,16,21,30]$. The melatonin treatment also produced a similar model of daily melatonin levels as re-
$>1 \mathrm{ng} / \mathrm{mL}$ (Figure 4). Progesterone mean values above $1 \mathrm{ng} / \mathrm{mL}$ were observed only in three of six implanted Romney Marsh ewes. No elevation of plasma progesterone concentrations was observed in no-implanted Romney Marsh ewes (Figure 5).
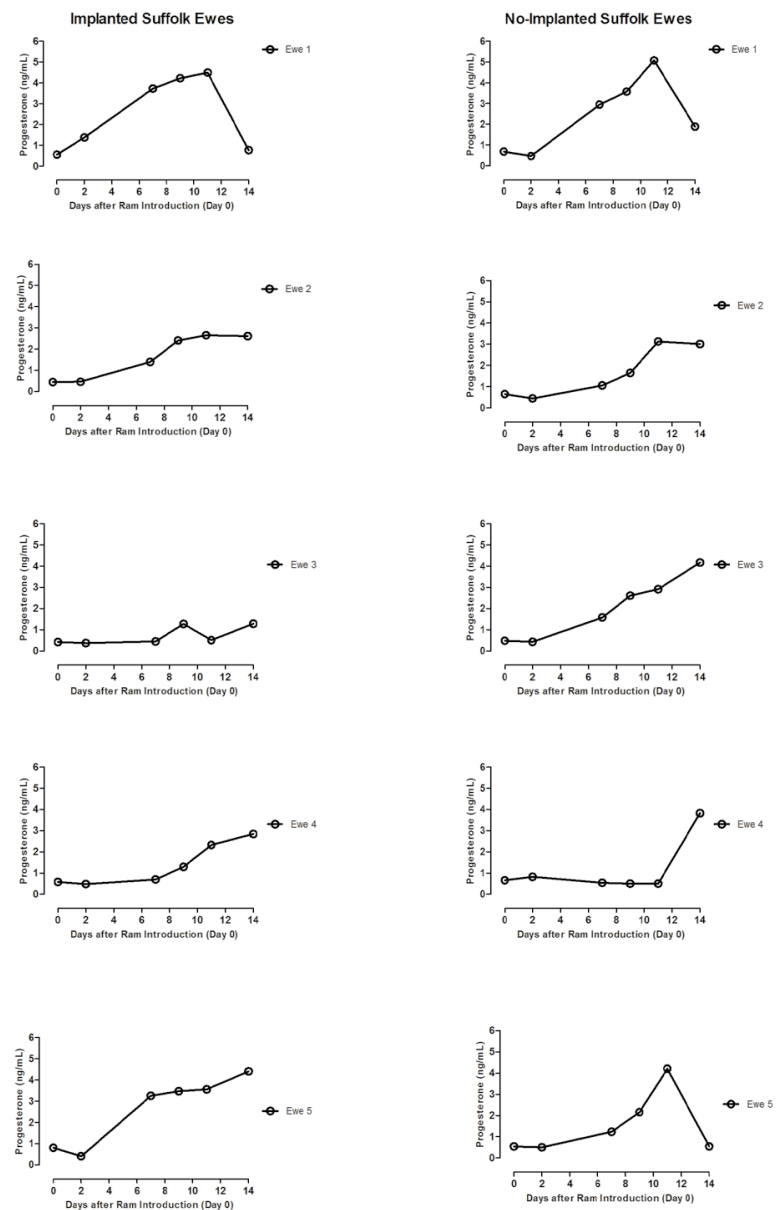

Figure 5. Individual plasma progesterone concentrations in melatonin implanted and no-implanted Romney Marsh ewes determined at the same day of the introduction of the rams (Day 0) and 46 days after melatonin implantation.

ported previously by others $(9,12,13,17,28,33,39]$, which is characterized by high plasma melatonin concentrations during the light phase of the day.

In the present study, the effect of melatonin implants on plasma melatonin profiles interacted with breed. In Suffolk implanted ewes there was no difference between dark-phase and the light-phase periods on plasma melatonin levels, but the exogenous melatonin from implant was additive to the endogenous dark-phase production (Table 1). In Romney Marsh implanted ewes the plasma melatonin levels were higher during the darkphase than the light-phase of the day, as reported previously in literature $[2,9,13,26]$. However, the implanted 
Romney Marsh ewes showed a weak response to melatonin implantation by increasing the plasma melatonin profile during the dark-phase (Table 2). In those animals the effect of melatonin implantation inducing a significant high melatonin levels was observed only the light-phase of the day. In general, the alterations of the 24-h blood melatonin profiles by melatonin treatment also seem to be varied according to the breed (Figure 1). The present findings do not allow definitive conclusions regarding breed differences on daily melatonin profiles in response to melatonin implantation because only 5 to 6 animals per breed were studied but, they do suggest a individual response to melatonin implantation which is proportional to genetic individual variation pattern of melatonin secretion $[25,38]$. In fact, it has been demonstrated a repeatable individual variability on amplitude and duration of the plasma melatonin concentration melatonin in ewes [6], but the plasma concentrations of melatonin are quite stable within the same individual [19].

The results regarding plasma progesterone concentrations showed that before the melatonin implantation all Romney Marsh and Suffolk ewes were judged to be in non-ovulatory period (anoestrus) with plasma progesterone mean values lower than $1 \mathrm{ng} / \mathrm{mL}$. Peripheral progesterone concentrations have been used to monitor the cyclic reproductive activity in sheep [5,22,23,39]. Ewes were judged to be in anovulation if plasma progesterone concentration never exceeded $1 \mathrm{ng} / \mathrm{mL}$ for more than 2 consecutive samples or during a 10-d period $[22,23]$. After 7 days of ram and 46 days after melatonin implantation, an increase in plasma progesterone mean values above $1 \mathrm{ng} / \mathrm{mL}$ was observed in implanted Romney Marsh and implanted and no-implanted Suffolk ewes. In spite of the implanted Romney Marsh ewes showed an elevation of progesterone mean levels, this increase was more pronounced in implanted Suffolk ewes. This event probably happened because 3 of 6 implanted Romney Marsh ewes whereas 4 of 5 implanted Suffolk ewes showed an ovulatory response with progesterone levels above $1 \mathrm{ng} / \mathrm{mL}$. Our results suggest that melatonin treatment helped to induce the ovulatory activity in most of the ewes that were in anestrous at the time of melatonin implantation. It was also clear that efficacy of melatonin treatment in advancing the reproductive activity depends on the individual variation in ovulatory response to ram introduction. In fact, there is evidence that the melatonin treatment modifies the response of male effect in ewes [1] and goats [4,37]. Abecia et al. [1] reported that the proportion of ewes exhibiting ovarian activity in response to introduction of ram after melatonin treatment was $42 \%$. Others have observed ovarian activity 66 days [27] and 77 days [8] after the onset of melatonin treatment. In the present study, the plasma progesterone concentrations to monitoring the ovulatory activity were evaluated only 60 days after the beginning of melatonin treatment.

On the other hand, all the 5 no-implanted Suffolk ewes presented an ovulatory response by increasing the plasma progesterone concentrations suggesting that for these ewes the male effect without melatonin treatment is sufficient to induce the ovulatory activity. The introduction of male to previously separated anovulatory females can induce female estrous activity [31] and this strategy is an important component of reproductive management to anticipate the breeding season under field conditions at lower latitudes [32]. It has been demonstrated that the efficacy of the ovulatory response to male effect varied according to the degree of reproductive seasonality of the ewe [31]. In our previous studies, it was indicated that the breeding season of Romney Marsh ewes was more restricted than the breeding season of Suffolk ones $[7,29]$. In the present study, it seems that no-implanted Suffolk ewes appear to have a slight anoestrus [31] and could respond to introduction of rams by increasing the plasma progesterone concentrations.

In conclusion, under natural lighting at 21059'S, melatonin implant altered the daily plasma melatonin profiles of Suffolk and Romney Marsh ewes by increasing the melatonin levels during the light-phase of the day. Melatonin implant also induced an ovulatory response in Suffolk and Romney Marsh ewes by increasing the plasma progesterone concentrations after the introduction of the rams. For no-implanted Suffolk ewes, the male effect is sufficient to provoke an ovulatory response with progesterone levels above to $1 \mathrm{ng} / \mathrm{mL}$.

\section{MANUFACTURERS}

${ }^{1}$ CEVA Salud Animal, S.A. Barcelona, Spain.

${ }^{2}$ Diagnostic Products Company. Los Angeles, CA, USA.

Acknowledgments. To Fundação de Amparo à Pesquisa do Estado de São Paulo (FAPESP) for financial support.

Ethical approval. All the procedures were performed in accordance with local Ethics Committee for Animal Experiments (CEUA No. 613818115) and Brazilian guidelines for the protection of experimental animals (CONCEA).

Declaration of interest. The authors report no conflicts of interest. The authors alone are responsible for the content and writing of the paper. 


\section{REFERENCES}

1 Abecia J.A., Palacín I., Forcada F. \& Valares J.A. 2006. The effect of melatonin treatment on the ovarian response of ewes to the ram effect. Domestic Animal Endocrinology. 31: 52-62.

2 Arendt J., Symons A.M. \& Laud C. 1981. Pineal function in the sheep: evidence for a possible mechanism mediating seasonal reproductive activity. Experientia. 37: 584-586.

3 Arendt J., Symons A.M., English J., Poulton A.L. \& Tobler I. 1988. How does melatonin control seasonal reproductive cycles? Reproduction, Nutrition and Development. 28: 387-397.

4 Celi I., Gatica M.C., Guzmán J.L., Gallego-Calvo L. \& Zarazaga L.A. 2013. Influence of the male effect on the reproductive performance of female Payoya goats implanted with melatonin at the winter solstice. Animal Reproduction Science. 137: 183-188.

5 Cerna C., Porras A., Valencia M.J., Perera G. \& Zarco L. 2000. Effect of an inverse subtropical (19²13N) photoperiod on ovarian activity, melatonin and prolactin secretion in Pelibuey ewes. Animal Reproduction Science. 60: 511-525.

6 Chemineau P., Beltrán De Heredia I., Deveau A. \& Bodin L. 1996. High repeatability of the amplitude and duration of the nycthemeral rhythm of the plasma melatonin concentration in the Ile-de-France ewe. Journal Pineal Research. 21: 1-6.

7 Coelho L.A., Rodrigues P.A., Nonaka K.O., Sasa A., Balieiro J.C.C., Vicente W.R.R. \& Cipolla-Neto J. 2006. Annual pattern of plasma melatonin and progesterone concentrations in hair and wool ewe lambs under natural photoperiod at lower latitudes in southern hemisphere. Journal Pineal Research. 41:101-107.

8 Donovan A., Boland M.P., Roche J.F. \& O'Callaghan D. 1994. The effect of supplementary long days, a subcutaneous melatonin implant and exposure to ram on the onset of the breeding season in ewes. Animal Reproduction Science. 34: 231-240.

9 Durotoye L.A., Rajkumar R., Argo C.M., Nowak R., Webley G.E., McNeil M.E., Graham N.B. \& Rodway R.G. 1991. Effect of constant-release melatonin implants on the onset of estrous activity and on reproductive performance in the ewe. Animal Production. 52: 489-497.

10 English J., Pouton A.L., Arendt J. \& Symons A.M. 1986. A comparison of the efficiency of melatonin treatments in advancing oestrus in ewes. Journal Reproduction Fertility. 77: 321-327.

11 Forcada F., Abecia J.A., Casao A., Cebrián-Perez J.A., Muiño-Blanco T. \& Palacín I. 2007. Effects of ageing and exogenous melatonin on pituitary responsiveness to GnRH in ewes during anestrus and the reproductive season. Theriogenology. 67: 855-862.

12 Forcada F., Abecia J.A., Zúñiga O. \& Lozano J.M. 2002. Variation in the ability of melatonin implants inserted at two different times after the winter solstice to restore reproductive activity in reduced seasonality ewes. Australian Journal of Agricultural Research. 53(2): 167-173.

13 Forcada F., Zarazaga L. \& Abecia J.A. 1995. Effect of exogenous melatonin and plane of nutrition after weaning on estrous activity, endocrine status and ovulation rate in Salz ewes lambing in the seasonal anestrus. Theriogenology. 43: 1179-1193.

14 Frazer S., Cowen P., Franklin M., Franey C. \& Arendt J. 1983. Direct radioimmunoassay for melatonin in plasma. Clinical Chemistry. 29: 396-397.

15 Goldman B.D. 1999. The circadian timing system and reproduction in mammals. Steroids. 64: 679-685.

16 Guerin M.V., Watson R., McLoughney J., Earle C., Seamark R.F. \& Matthews C.D. 1989. The annual patterns of serum melatonin in Romney-Marsh sheep held in natural photoperiodic conditions. Advances in Pineal Research. 3: 137-141.

17 Kennaway D.J., Gilmore T.A. \& Seamark R.F. 1982. Effect of melatonin implants on the circadian rhythm of plasma melatonin and prolactin in sheep. Endocrinology. 110: 2186-2188.

18 Köppen W. 1948. Climatologia. Buenos Aires: Panamericana, 478 p.

19 Malpaux B., Moenter S.M., Wayne F.J., Woodfill C.J.I. \& Karsch F.J. 1988. Reproductive refractoriness of the ewe to inhibitory photoperiodic is not caused by alteration of the circadian secretion of melatonin. Neuroendocrinology. 48: 264- 270.

20 Malpaux B., Viguié C., Skinner D.C., Thiéry J.C. \& Chemineau P. 1997. Control of the circanual rhythm of reproduction by melatonin in the ewe. Brain Research Bulletin. 4: 431-438.

21 Matthews C.D., Seamark R.F. \& Guerin M.V. 1992. Plasma melatonin profiles of Romney Marsh sheep in natural photoperiod and in acutely extended darkness. Journal of Reproduction and Fertility. 95: 869-875. 
22 Minton J.E., Coppinger T.R., Spaeth C.W. \& Martin L.C. 1991. Poor reproductive response of anoestrous Suffolk ewes to ram exposure is not due to failure to secrete luteinizing hormone acutely. Journal Animal Science. 69: 33143320.

23 Minton J.E. 1990. Role of photorefractoriness in onset of anoestrous in Ramboullet X Dorset ewes. Journal of Reproduction and Fertility. 89: 261-268.

24 National Research Council. 1985. Nutrient requirements of domestic animals: nutrient requirements of sheep. 6th edn. Washington: D.C. National Academy Press, 99p.

25 Notter D.R. \& Chemineau P. 2001. Nocturnal melatonin and prolactina plasma concentrations in sheep selected for fertility in autumn lambing. Journal of Animal Science. 79: 2895-2901.

26 Rekik M., Bryant M.J. \& Cunningham F.J. 1991. Effects of treatment with melatonin on the response of seasonally anovular ewes to the introduction of rams. Animal Production. 53: 203-217.

27 Robinson J.J., Wallace J.M., Aitken R.P. \& McNeilly A.S. 1993. Effect of chronic treatment with a GnRH agonist to suppress pulsatile LH secretion on the ability of exogenous melatonin to advance oestrous cyclicity in ewes. Journal of Reproduction and Fertility. 99: 601-608.

28 Robison J.J., Wigzell S., Aitken R.P., Wallace J.M., Ireland S. \& Robertson I.S. 1991. The modifying effects of melatonin, ram exposure and plane of nutrition on the onset of ovarian activity, ovulation rate and the endocrine status of ewes. Animal Reproduction Science. 26: 73-91.

29 Rodrigues P.A., Coelho L.A., Nonaka K.O., Sasa A., Vicente W.R.R., Balieiro J.C.C. \& Siqueira E.R. 2007. Annual characteristics of estrous activity in wool and hair ewe lambs under subtropical conditions. Scientia Agricola. 64: 468-475.

30 Rollag M.D., O’Callagham P.L. \& Niswender G.D. 1978. Serum melatonin concentrations during different stages of the annual reproductive cycle in ewes. Biology of Reproduction. 18: 279-285.

31 Rosa H.J.D. \& Bryant M.J. 2002. The 'ram effect' as a way of modifying the reproductive activity in the ewe. Small Ruminant Research. 45: 1-16.

32 Sasa A., Nonaka K.O., Balieiro J.C.C. \& Coelho L.A. 2011. Progesterona plasmática de ovelhas submetidas ao efeito-macho e mantidas sob diferentes condições nutricionais. Arquivo Brasileiro de Medicina Veterinária Zootecnia. 63: 1066-1072.

33 Staples L.D., McPhee S., Kennaway D.J. \& Williams A.H. 1992. The influence of exogenous melatonin on the seasonal patterns of ovulation and oestrus in sheep. Animal Reproduction Science. 30: 185-223.

34 Statistical Analysis System Institute. 1995. SAS User's Guide, Release 8.0.2, Cary. SAS Institute.

35 Thimonier J. \& Mauléon P. 1969. Variations saisonnières du comportement dóestrus et des activités ovarienne et hypophysaire chez les ovins. Annales de Biologie Animale, Biochimie, Biophysique. 9: 223-250.

36 Viguié C., Thibault J., Thiéry J.C., Tillet Y. \& Malpaux B. 1997. Characterization of the short day-induced decrease in median eminence tyrosine hydroxylase activity in the ewe: Temporal relationship to the changes in luteinizing hormone and prolactina secretion and short day-like effect of melatonin. Endocrinology. 138: 499-506.

37 Zarazaga L.A., Celi I., Guzmán J.L. \& Malpaux B. 2012. Enhancement of male effect on reproductive performance in female Mediterranean goats with long day and/or melatonin treatment. The Veterinary Journal. 192: 441-444.

38 Zarazaga L.A., Malpaux B., Bodin L. \& Chemineau P. 1998. The large variability in melatonin blood levels in ewes is under strong genetic influence. American Journal of Physiology, Endocrinology and Metabolism. 274: 607-610.

39 Zúñiga O., Forcada F. \& Abecia J.A. 2002. The effect of melatonin implants on response to male effect on the subsequent cyclicity of Rasa Aragonesa ewes implanted in April. Journal Animal Science. 72: 165-174. 